\title{
PATTERNS OF SPECIES RICHNESS AND DIVERSITY OF WILLOW SALIX ALBA L. PESTS IN THE WEST AZERBAIJAN PROVINCE OF IRAN
}

\author{
YASAMAN, S. H. ${ }^{1 *}-$ REZA, V. ${ }^{1}-$ MOHAMMED, R. Z. ${ }^{2}-$ BAHMAN, S. H. ${ }^{1}$ \\ ${ }^{1}$ Department of Entomology, Faculty of Agriculture, Islamic Azad University, \\ Arak Branch, Arak, Iran \\ ${ }^{2}$ Department of Forestry, Faculty of Natural Resources, Urmia University, \\ Urmia, Iran \\ *Corresponding author \\ e-mail: Yasamanshafighi@gmail.com \\ phone:+989143492513; fax: +984433676479 \\ (Received $17^{\text {th }}$ Nov 2016; accepted $28^{\text {th }}$ Feb 2017)
}

\begin{abstract}
One of the most important renewable resources in nature, is species of Salix alba L. var. alba from Salicaceae family. Salix alba trees are under attack by various pests. Given the importance of $S$. $a l b a$ in the West Azerbaijan Province of Iran, S. alba pest species richness was measured in five watersheds. In each region, 10 bases of $S$. alba species were randomly selected to estimate the indices of species prevalence and richness for $S$. alba pests. A total of 21 pests species of $S$. alba was collected from the study area. The highest species richness for pests was estimated in Baranduz, Zangmar and Mahabad in May, July and October with 20.9, 21.9 and 8.9 species (based on rarefaction estimation) respectively. Moreover, the highest Simpson, Shannon, and Brillouin diversity indices observed in Mahabad region were $0.87,3.39$, and 3.34 , respectively which suggest this area has the highest diversity of pest in entire study area. The findings of this study suggests that difference in climatic conditions and occurrence of different subspecies of $S$. alba may be the driving forces behind the various patterns of pest diversity observed in the study areas.
\end{abstract}

Keywords: biodiversity, distribution, frequency, index, pests

\section{Introduction}

Salix alba L. is a species of willow known as white willow which grows usually in Europe and western and central Asia. S. alba trees are characterized by fast growth, easy propagation, tendency to transplant and beautiful appearance, along with many other uses that make these trees very attractive and useful (Stettler, 2011). Supplying wood, fiber and fuel wood are further advantages of $S$. alba trees. Planting $S$. albas are beneficial from social and economic aspects. Their planting is also effective in restoring degraded lands and forest landscape, and reducing soil erosion and preventing climate change (Stettler, 2011). In 8000 BC, Native Americans used S. alba trees for cooking, heating, shelter, and medicine (the precursor of modern aspirin) (Hageneder, 2005). White $S$. alba bark was used for medicinal purposes, as tannins for painting the silk, wool and leather, and for the production of buff leather covering, and for painting and making rope (Belyaeva, 2009). In a review on $S$. alba and poplar pest in Iran, a number of 23 pests were reported as common pests of $S$. alba and poplar and 8 pests were reported as specific pests of $S$. alba (Sadeghi et al., 2009). Based on the type of damage imposed, insects include $S$. alba gall-inducing insects, sap-sucking insects, insects feeding on leaves, wood-boring insects, and non-gall-inducing mites. Not all species of 
pests on $S$. alba have been precisely identified in the country until now (Abai, 2009; Ashori and Kheradpir, 2009).

Biodiversity includes all the variety and variability of living organisms, within communities and within ecological sights and even between them and their performances (Sandlund et al., 1992). S. alba trees provide habitats for rich biodiversity of pests, in their native environments all around the world. Biodiversity, in fact, is a combination of all biological diversity including genetic diversity within species, diversity between species, and between and within communities and ecosystems of a region (Hawksworth and Kalin-Arroyo, 1995). It includes all the variability within and among organisms, communities and ecosystems (Magurran, 2013). The more species' diversity is in an ecosystem, the healthier, more sustainable, and self-regulatory it is. Therefore, biodiversity in an area should be considered as a key to its sustainability and resiliency (Schowalter, 2006; Speight et al., 1999). The aim of this study was to determine the $S$. alba pest species richness in West Azerbaijan Province of Iran.

\section{Materials and Methods}

Different species of $S$. alba are scattered around the watersheds in West Azerbaijan Province, Iran. In this study, five sites (watersheds) including Zangmar, Mahabad, Baranduz, Zola, and Zab were selected for sampling. The information of these regions in terms of latitude, temperature, and humidity are shown in (Table 1). Sampling locations are marked with an asterisk in (Fig. 1).

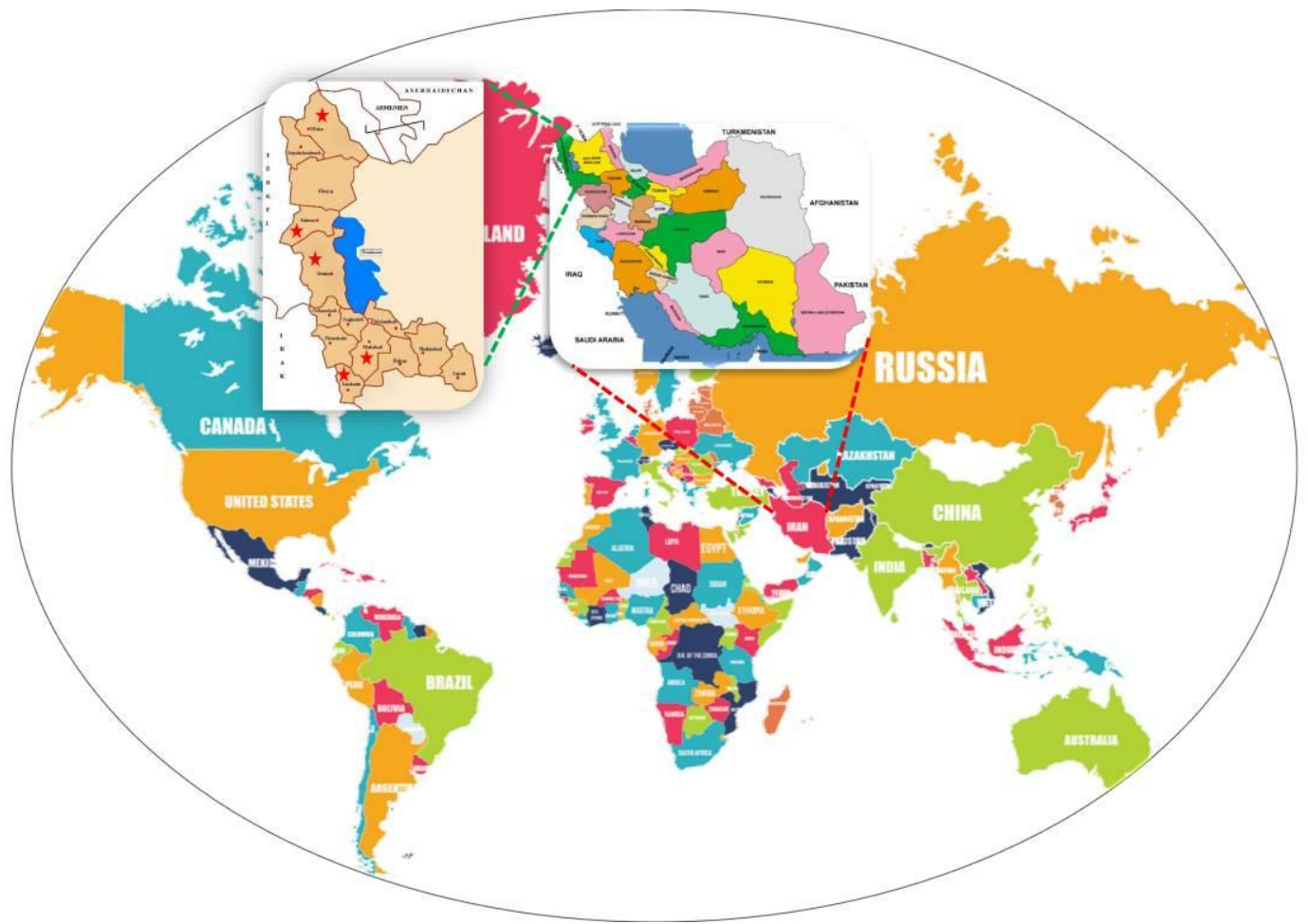

Figure 1. Location of the study areas 
Table 1. Characteristics of sampling sites in West Azerbaijan Province, Iran in 2015

\begin{tabular}{cccccc}
\hline Sites & Latitude/Longitude & Climate & Temperature & Humidity & $\begin{array}{c}\text { Willow } \\
\text { species }\end{array}$ \\
\hline Zangmar & $39^{\circ} 16^{\prime} \mathrm{N} 44^{\circ} 32^{\prime} \mathrm{W}$ & High humid, cold & $-4.5-24.4{ }^{\circ} \mathrm{C}$ & $34-64 \%$ & Salix alba \\
Mahabad & $36^{\circ} 46^{\prime} \mathrm{N} 45^{\circ} 42^{\prime} \mathrm{W}$ & High humid, cold & $0.1-27{ }^{\circ} \mathrm{C}$ & $45-54 \%$ & Salix alba \\
Baranduz & $37^{\circ} 30^{\prime} \mathrm{N} 45^{\circ} 7^{\prime} \mathrm{W}$ & Cold semi-arid & $-2.5-25{ }^{\circ} \mathrm{C}$ & $46-78 \%$ & Salix alba \\
Zola & $38^{\circ} 7^{\prime} \mathrm{N} 44^{\circ} 41^{\prime} \mathrm{W}$ & $\begin{array}{c}\text { High humid, } \\
\text { Mediterranean }\end{array}$ & $-3.7-26.2{ }^{\circ} \mathrm{C}$ & $54-82 \%$ & Salix alba \\
Zab & $36^{\circ} 57^{\prime} \mathrm{N} 45^{\circ} 23^{\prime} \mathrm{W}$ & Wet Mediterranean & $1.1-27.4{ }^{\circ} \mathrm{C}$ & $20-86 \%$ & Salix alba \\
\hline
\end{tabular}

Sampling was done three times in May, July, and October in 2015. Ten S. alba species were selected from each site, and aerial parts of the trees were studied in four main directions. The trees were randomly selected as two +- shaped and two $\times$-shaped diameters. In order to eliminate the marginal effects, sampling was performed from the central part. After determining the sampling locations of $S$. alba in each site, four branches from each tree base at the height of 1.5-2 m were examined. After sampling from tree branches, samples were put inside the bags, each bag was labeled with the information of the sampling date and location, and then taken to the laboratory of Forestry Group in the Faculty of Natural Resources, at Urmia University for identification. The newly selected samples and unknown types of them were characterized by the researchers in the modern and well-equipped laboratories of Agricultural Research, Education \& Extension Organization (AREEO) (Zahra Hashemi Khabir) and Research Institute of Forests and Rangelands of Iran (Mehri Bab Morad). It is important to mention that, both centers have expert researchers on the Willow and detection and evaluation of Willow insect pests.

\section{Calculation of optimum sample size}

The following formula was used for calculating the required sample size (Southwood and Henderson, 2009):

$$
\mathrm{N}=[\mathrm{t} \times \mathrm{s} / \mathrm{d} \times \mathrm{m}]^{2}
$$

where:

$\mathrm{t}$ : numerical value of $\mathrm{t}$-student in terms of degrees of freedom

s: standard deviation of the initial sampling

$\mathrm{d}$ : error value $(0.2)$

$\mathrm{m}$ : mean of pilot sampling data

$\mathrm{N}$ : number of samples required

It is worth noting that the relative error of primary sampling (RV) was estimated less than $25 \%$. 


\section{Calculation of species' diversity indices}

Simpson's diversity index is one of the most important indices measuring heterogeneity and the first non-parametric diversity index (Ejtehadi et al., 2009).

$$
\text { Simpson's diversity index }=1-\mathrm{D}=1-\sum_{i=1}^{N} \frac{n_{i}\left(n_{i}-1\right)}{N(N-1)}
$$

where $\mathrm{n}_{\mathrm{i}}$ is the number of individuals of ith species in the sample, and $\mathrm{N}$ is the total number of individuals in the sample.

$\mathrm{H}^{\prime}$ is Shannon's diversity index which represents an estimation of the average degree of uncertainty in predicting the belonging of an individual randomly selected from a set of s species and of N individuals (Ejtehadi et al., 2009; Magurran, 2013).

$$
\text { Shannon's } \mathrm{H}^{\prime}=-\sum_{i=1}^{N_{o}}\left[p_{i} * \log p_{i}\right]
$$

where $\mathrm{Pi}$ is the proportion of individuals in ith species to the total sample, defined as $\mathrm{ni} / \mathrm{N}=\mathrm{Pi}$.

Brillouin's diversity index is:

$$
\hat{H}=\frac{1}{N} \log \left(\frac{N !}{n_{1} ! n_{2} ! n_{3} ! \cdots}\right)
$$

Where $\mathrm{N}$ is the total number of individuals, $\mathrm{n} 1$ is the number of individuals belonging to species $1, \mathrm{n} 2$ is the number of individuals belonging to species 2 , and $\mathrm{n} 3$ is the number of individuals belonging to species 3 .

\section{Calculation of uniformity indices}

Evenness is considered as a measurement criterion for determining the evenness and lack of abundance of each species in a class of samples, or in a given population (Alatalo, 1981; Stirling and Wilsey, 2001). One of the simplest ways of calculation of uniformity is dividing the heterogeneity index by its maximum value (Krebs, 1989).

Uniformity of species in every area was calculated by Simpson's and Shannon's uniformity indices.

The Simpson's uniformity index is:

$$
E_{1 / D}=\frac{1 / \hat{D}}{S}
$$

where D is Simpson's index. 
In Shannon's uniformity index, a base logarithm is used. The Shannon's uniformity index is:

$$
\mathrm{E}=\mathrm{H}^{\prime} / \mathrm{Hmax}=\mathrm{H}^{\prime} / \ln \mathrm{S} \text {. }
$$

Camargo's uniformity index is:

$$
E^{\prime}=1 . .0-\left(\sum_{i=1}^{s} \sum_{j=i+1}^{s}\left[\left|p_{i}-p_{j}\right| / s\right]\right)
$$

where $\mathrm{Pi}$ is the proportion of species $\mathrm{i}$ in the total sample; $\mathrm{Pj}$ is the proportion of species $\mathrm{j}$ in the total sample; and $\mathrm{S}$ is the total number of species.

The formula to calculate the species richness by Rarefaction method is as follows:

$$
E\left(\hat{S}_{n}\right)=\sum_{i=1}^{s}\left[1-\frac{\left(\begin{array}{c}
N-N_{i} \\
n
\end{array}\right)}{\left(\begin{array}{l}
N \\
n
\end{array}\right)}\right]
$$

where:

$E\left(S_{n}\right)=$ number of species expected in the random sampling with an individual $\mathrm{S}=$ total number of species in the collection

$\mathrm{Ni}=$ number of people in I-the species

$\mathrm{N}=$ total number of individuals in sampling $\mathrm{n}=$ the sample size (number of people) selected for standardization $(\mathrm{n} \leq \mathrm{N})$

$\left[\begin{array}{l}\mathrm{N} \\ \mathrm{n}\end{array}\right]$ = number of combinations of $\mathrm{n}$ people, which can be selected from a group of $\mathrm{N}$ individuals (Schowalter, 2006).

$$
=\mathrm{N} ! \mathrm{n} !(\mathrm{N}-\mathrm{n}) \text { ! }
$$

The formula to calculate the species richness by Jackknife method is as follows:

$$
\hat{S}=s+\left(\frac{n-1}{n}\right) k
$$

where:

$\hat{\mathrm{S}}=$ Jackknife species richness

$\mathrm{s}=$ total number of species observed in the $\mathrm{n}$ samples

$\mathrm{n}=$ total number of sampling units 
$\mathrm{k}=$ number of rare samples (rare sample is the one that appears in only one of the sampling units)

Calculation of species' diversity indices, uniformity indices, as well as species' richness of $S$. alba pests were performed by statistical diversity software Ecological Methodology 6.0.

\section{Results}

According to the studies conducted in 2015 at five sites (Fig. 1), by three sampling stages in May, July, and October, 21 pest species were collected from $S$. alba trees in West Azerbaijan Province (Table 2). The results obtained showed that in general, the highest abundance of pests was recorded in July in Zangmar, and the lowest abundance was recorded in October in Zab (Fig. 2). Of these 21 pest species, some pests were not observed in some of the areas: Amorpha populi in Zangmar and Zab; Timarcha tenebricosa in Mahabad and Zab; Plagiodera versicolora in Zab; and Pontania vesicator in only Zab, indicating that these pests probably do not prefer wet places (Table 2).

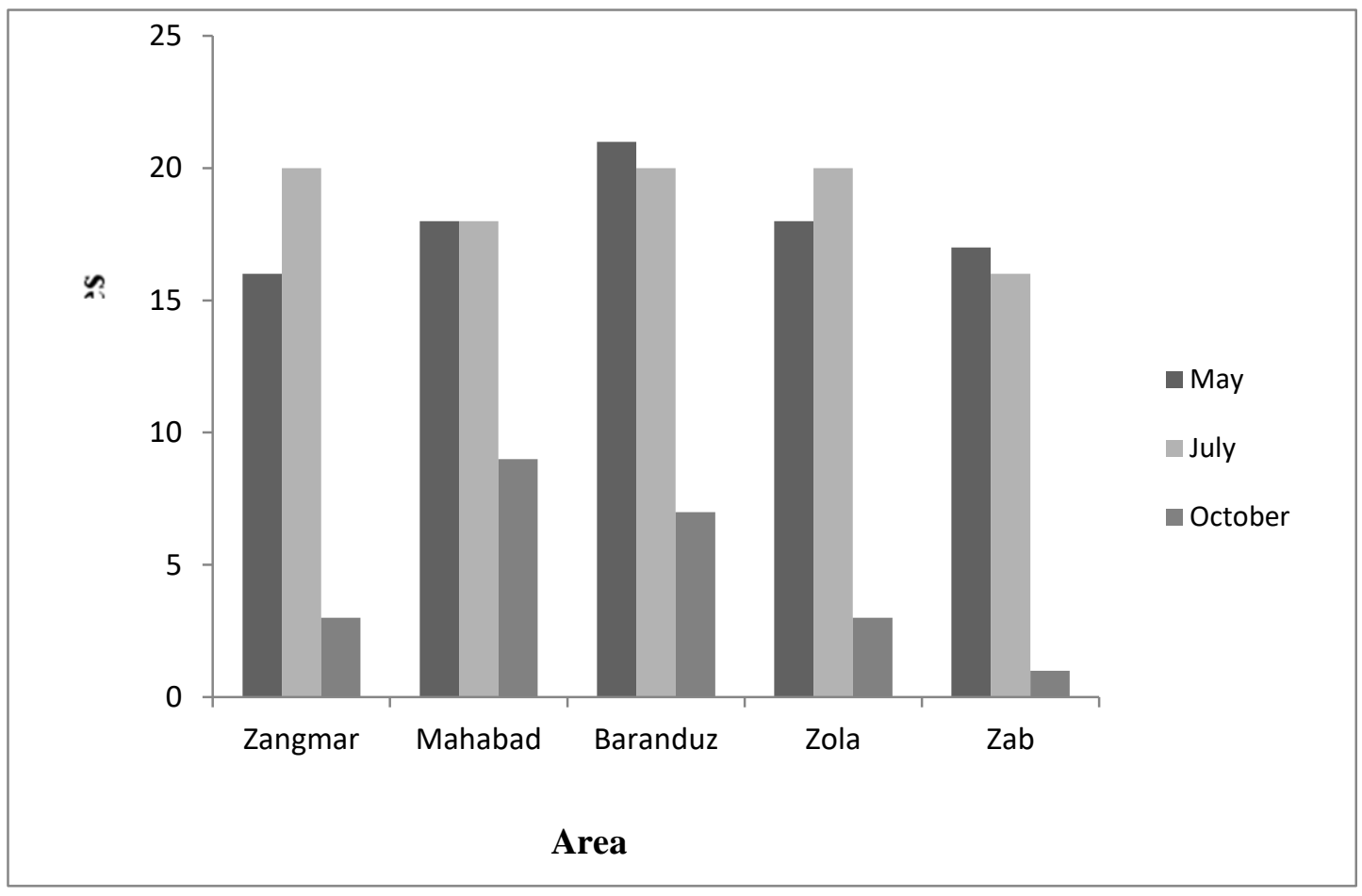

Figure 2. Frequency of occurrence of Salix alba pest species in study areas at different time intervals in West Azerbaijan Province, Iran

In general, the maximum value of Simpson's diversity index (0.78) was observed in May in Mahabad, which was due to the low number of the species collected and their partly close abundance. The minimum value of Simpson's diversity index (0.43) was in July in Zangmar, which was due to the highly differentiated abundance of the species collected. The maximum value of Shannon's diversity index (3.39) was recorded in 
May in Mahabad. Its minimum value (1.22) was in October in Zangmar, which was likely due to its ultra-cold, Mediterranean climate compared to other areas (Table 3).

A comparison of uniformity indices among five areas indicated that the maximum value of Simpson's uniformity index was 0.77 in October in Zola, which was because of the low number of the species and higher chance of equal species abundance. The minimum value of Simpson's uniformity index (0.08) was recorded in Zangmar, representing a highly different abundance of the species collected. As for Shannon's uniformity index, calculations showed that in five study stations, the maximum value (0.83) was observed in October in Zola, which was related to the high abundance of the species collected. Its minimum value (0.4) was observed in Zangmar, which was because of the low number of the species and their low abundance (Table 4).

Table 2. The introduction of pests collected from five watersheds in West Azerbaijan Province, Iran and the overall frequency of them

\begin{tabular}{|c|c|c|c|c|c|c|c|}
\hline Row & Area & Family & Zangmar & Mahabad & Baranduz & Zola & Zab \\
\hline 1 & Aphis farinosa (Gmelin, 1790) & Aphididae & $20 / 374$ & $11 / 96$ & $8 / 587$ & $22 / 834$ & $11 / 22$ \\
\hline 2 & $\begin{array}{l}\text { Eriophyes tetanothrix (Nalepa, } \\
1898 \text { ) }\end{array}$ & Eriophyidae & $50 / 328$ & $15 / 324$ & $3 / 135$ & $24 / 031$ & $1 / 338$ \\
\hline 3 & $\begin{array}{c}\text { Pontania vesicator (Bremi- } \\
\text { Wolf, 1849) }\end{array}$ & Tenthredinidae & $0 / 452$ & $7 / 475$ & $3 / 107$ & $2 / 262$ & 0 \\
\hline 4 & $\begin{array}{l}\text { Monosteria unicostata } \\
\text { (Mulsant \& Rey, 1852) }\end{array}$ & Tingidae & $6 / 517$ & $19 / 741$ & $47 / 546$ & $15 / 318$ & $33 / 813$ \\
\hline 5 & $\begin{array}{l}\text { Chaitophorus niger } \\
\text { (Mordvilko, 1929) }\end{array}$ & Aphididae & $7 / 01$ & $16 / 343$ & $11 / 859$ & $19 / 817$ & $25 / 78$ \\
\hline 6 & $\begin{array}{l}\text { Lepidosaphes malicola } \\
\text { (Borchsenius, 1947) }\end{array}$ & Diaspididae & $1 / 953$ & $3 / 635$ & $6 / 515$ & $3 / 198$ & $3 / 707$ \\
\hline 7 & $\begin{array}{c}\text { Tuberolachnus } \\
\text { salignus(Gmelin, 1790) }\end{array}$ & Aphididae & $2 / 754$ & $3 / 907$ & $3 / 8$ & $2 / 522$ & $6 / 282$ \\
\hline 8 & $\begin{array}{c}\text { Eulecanium coryli (Cockerell, } \\
\text { 1901) }\end{array}$ & Coccidae & $0 / 925$ & $0 / 339$ & $1 / 008$ & $0 / 546$ & $1 / 544$ \\
\hline 9 & $\begin{array}{l}\text { Lithocolletis salicicolla } \\
\text { (Linnaeus, 1758) }\end{array}$ & Lithocolletidae & $1 / 212$ & $0 / 88$ & $0 / 954$ & $0 / 546$ & $0 / 652$ \\
\hline 10 & $\begin{array}{c}\text { Rhabdophaga rosaria }(\mathrm{H} . \\
\text { Loew, 1850) }\end{array}$ & Cecidomyiidae & $0 / 123$ & $0 / 203$ & $2 / 181$ & $0 / 39$ & $0 / 583$ \\
\hline 11 & $\begin{array}{c}\text { Cacopsylla pulchra } \\
\text { (Zetterstedt, 1840) }\end{array}$ & Psyllidae & $1 / 048$ & $1 / 291$ & $0 / 845$ & $0 / 91$ & 0/961 \\
\hline 12 & $\begin{array}{c}\text { Amorpha populi (Linnaeus, } \\
1758 \text { ) }\end{array}$ & Sphingidae & 0 & $0 / 169$ & $0 / 136$ & $0 / 026$ & 0 \\
\hline 13 & $\begin{array}{c}\text { Eriophyes triradiatus (Nalepa, } \\
1892 \text { ) }\end{array}$ & Eriophyidae & $0 / 205$ & $0 / 237$ & $0 / 817$ & $0 / 572$ & $1 / 029$ \\
\hline 14 & $\begin{array}{c}\text { Chinoaspis salicis (Linnaeus, } \\
1758 \text { ) }\end{array}$ & Diaspididae & $1 / 624$ & $9 / 989$ & $2 / 48$ & $1 / 456$ & $5 / 183$ \\
\hline 15 & $\begin{array}{c}\text { Thrips viminalis } \\
\text { (Uzel, 1895) }\end{array}$ & Thripidae & $1 / 377$ & $1 / 8$ & $2 / 317$ & $1 / 274$ & $2 / 197$ \\
\hline 16 & $\begin{array}{l}\text { Plagiodera versicolora } \\
\text { (Laicharting, 1781) }\end{array}$ & Chrysomelidae & $0 / 699$ & $0 / 44$ & $0 / 354$ & $0 / 13$ & 0 \\
\hline 17 & $\begin{array}{l}\text { Timarcha tenebricosa } \\
\text { (Fabricius, 1775) }\end{array}$ & Chrysomelidae & $0 / 102$ & 0 & $0 / 218$ & $0 / 052$ & 0 \\
\hline 18 & $\begin{array}{l}\text { Chloroclysta miata } \\
\text { ( Linnaeus, 1758) }\end{array}$ & Geometridae & $0 / 287$ & $0 / 747$ & $0 / 381$ & $0 / 364$ & $0 / 48$ \\
\hline 19 & $\begin{array}{c}\text { Chrysomela populi (Stephens, } \\
1834)\end{array}$ & Chrysomelidae & $0 / 534$ & $1 / 359$ & $1 / 226$ & 0/91 & $1 / 33$ \\
\hline 20 & $\begin{array}{c}\text { Tetranychus urticae (Koch, } \\
1836)\end{array}$ & Tetranychidae & $1 / 912$ & $3 / 567$ & $2 / 562$ & $2 / 21$ & $3 / 364$ \\
\hline 21 & $\begin{array}{c}\text { Theria rupicapraria (Denis \& } \\
\text { Schiffermüller, 1775) }\end{array}$ & Geometridae & $0 / 55$ & $0 / 577$ & $0 / 681$ & $0 / 642$ & $0 / 61$ \\
\hline
\end{tabular}


Table 3. Diversity indices calculated of S. alba in five watersheds in West Azerbaijan Province, Iran

\begin{tabular}{ccccc}
\hline \multirow{2}{*}{ Sites } & Season & \multicolumn{3}{c}{ Heterogeneity } \\
\cline { 2 - 5 } & & Simpson's index & Shannon's H' & Brillouin \\
\hline \multirow{3}{*}{ Zangmar } & Spring & 0.72 & 2.56 & 2.53 \\
& Summer & 0.43 & 1.73 & 1.7 \\
& Fall & 0.54 & 1.22 & 1.2 \\
\multirow{3}{*}{ Mahabad } & Spring & 0.87 & 3.39 & 3.34 \\
& Summer & 0.85 & 3.15 & 3.1 \\
& Fall & 0.76 & 2.48 & 2.39 \\
& Spring & 0.68 & 2.63 & 2.59 \\
Baranduz & Summer & 0.77 & 2.88 & 2.83 \\
& Fall & 0.73 & 2.23 & 2.12 \\
& Spring & 0.79 & 2.96 & 2.91 \\
Zola & Summer & 0.76 & 2.63 & 2.59 \\
& Fall & 0.56 & 1.31 & 1.28 \\
& Spring & 0.85 & 3.28 & 3.22 \\
& Summer & 0.73 & 2.47 & 2.44 \\
& Fall & Not calculated & Not calculated & Not calculated \\
\hline
\end{tabular}

Table 4. Evenness indices calculated for S. alba pests in five watersheds in West Azerbaijan Province, Iran

\begin{tabular}{cccccc}
\hline \multirow{2}{*}{ Sites } & Season & \multicolumn{4}{c}{ Evenness } \\
\cline { 3 - 6 } & Simpson's index & Shannon's H' & Camargo & $\begin{array}{c}\text { Smith and } \\
\text { Wilson }\end{array}$ \\
\hline \multirow{3}{*}{ Zangmar } & Spring & 0.23 & 0.64 & 0.3 & 0.299 \\
& Summer & 0.08 & 0.40 & 0.08 & 0.291 \\
& Fall & 0.73 & 0.77 & 0.73 & 0.44 \\
& Spring & 0.45 & 0.81 & 0.45 & 0.33 \\
Mahabad & Summer & 0.37 & 0.75 & 0.37 & 0.25 \\
& Fall & 0.47 & 0.78 & 0.48 & 0.33 \\
& Spring & 0.15 & 0.59 & 0.26 & 0.27 \\
Baranduz & Summer & 0.22 & 0.66 & 0.3 & 0.277 \\
& Fall & 0.52 & 0.79 & 0.52 & 0.49 \\
& Spring & 0.26 & 0.71 & 0.36 & 0.44 \\
& Summer & 0.21 & 0.60 & 0.24 & 0.22 \\
& Fall & 0.77 & 0.83 & 0.73 & 0.6 \\
Zab & Spring & 0.4 & 0.80 & 0.43 & 0.46 \\
& Summer & 0.23 & 0.62 & 0.282 & 0.285 \\
& Fall & Not calculated & Not calculated & Not calculated & Not calculated \\
\hline
\end{tabular}

\section{Discussion}

Mahabad and Baranduz regions had the highest number of species and diversity indices, which was located in the same climate (cold, semi-arid) and almost the same height. Many species were not observed in Zab, possibly due to its very cold, humid climate. In general, during three sampling dates, Zab had the lowest number of the species among all areas. Although Zab had almost the same tree heights with Mahabad 
and Baranduz, this discrepancy was probably observed because of its different climate (very cold, humid) compared to other four stations. All species collected in the research were observed in Zola, which was likely due to its different climate, suggesting that $S$. alba pests prefer ultra-cold, semi-arid areas more often. In contrast to Zola, Zab had the lowest number of the species collected owing to its humid climate. A high abundance of the pests collected in Mahabad and Baranduz (compared to Zola and Zab) resulted in an increase in species diversity indices.

Zangmar has a different climate from Mahabad and Baranduz. Twenty species with very low frequency and different abundance were collected from the area. The result showed a minimum diversity index in July and October. Of course, it is worth noticing that one specific and interesting factors affecting the diversity pests could be the diversity of $S$. alba subspecies that would affect the activity of pest species, in addition to climate. According to the frequency graphs (Tables 6-8), the results showed that the highest and lowest numbers of pests were observed in Zangmar in July and in Zab in October, respectively. The highest and lowest frequency of occurrence of pests were Eriophyes tetanothrix and Timarcha tenebricosa in Zangmar; Monosteria unicostata and Amorpha populi species in Mahabad; Monosteria unicostata and Amorpha populi species in Baranduz; E. tetanothrix and Amorpha populi species in Zola; and Monosteria unicostata and Chloroclysta miata species in Zab, respectively.

Aphis farinosa was one of the important pest species which was prevalent at five sites in May. This pest was not found in October at any of the sites. Most of these species were observed in Zangmar. Monosteria unicostata was one of the other important species. The highest and lowest numbers of this pest were observed in Baranduz and Zola in May, respectively. Lithocolletis salicicolla pest was observed in all regions. This pest continued its activity until October. Only in Zola and Zangmar, the date of its activity was in July and not in October in target areas. Melasoma populi pest was recorded in all target regions in the months of May and July, and it was not observed in any of the sites in October. The highest and lowest numbers were recorded in Baranduz and Zangmar, respectively. Amorpha populi pest had the lowest rate in all sites. As shown in (Table 5), the highest species richness according to Jackknife method (20.8 species) was seen in Baranduz in May. Species richness in Zangmar, Zola, and Zab was recorded to be zero in October, due to unfavorable climatic conditions in these areas, which reduce the frequency of pests and make the richness zero in these regions. Beyond these regions, the lowest species richness $(6.9$ species $)$ was recorded for Baranduz in October (Table 5). Monosteria unicostata species had the highest frequency (53.48) in May in Baranduz region which indicated the suitable climatic conditions for the activity of these species in the region.

The results of comparative study of the $S$. alba pest species richness using Rarefaction method in May, July, and October 2015 in five watersheds showed that the curve of the relationship between the number of trees in each sampling date and the number of species expected was increased. For example, if 500 trees were selected in May in Zangmar region, 15 to 16 pest species could be seen; the frequency of species was indeed the number of species observed in the region (16 species). A number of 500 individuals selected in Baranduz could result in species richness to be calculated between 21 and 20. Selecting 1,000 people in Baranduz region could show species richness of 20 or 21 , while selecting 1500 or 2000 (2,000 S. alba pests) could result in the same number of species ( 20 or 21 species). Thus, the results show that according to (Fig. 3), of 1000 individuals in the axis of $\mathrm{x}$, there is no need for additional sampling. 
And the number of the individuals selected (1000) gives accurate estimates of species richness (Fig. 4). The lack of Zab watershed curve in (Fig. 5) is due to the difference in climatic conditions between this region and other regions.

The comparison of four watersheds of Zangmar, Mahabad, Baranduz, and Zola regions of pest species frequency on different dates using Rarefaction method showed that the best period of richness was in July as it provided favorable climatic conditions for the breeding of pests in May. Hence, the most increase in richness was observed in July. Moreover, Zab watershed had the lowest number of species and richness due to different climatic conditions (too humid and cold) compared to other four watersheds (Fig. 6).

The results showed that in general, the highest and lowest numbers of $S$. alba pests were recorded in the regions of Zangmar and Zab, respectively; and the highest rates of Simpson and Shannon indices were seen in the region of Mahabad. According to the consistency of the calculated S. alba pest species richness by Rarefaction and Jackknife methods, and based on the number of species collected from 10 trees in each region in this study, the pest species richness can be estimated accurately. The diversity of $S$. alba pest species is required to be further investigated. There are special relations between gall-inducing wasp species and the host oak tree species. The factors that have a decisive influence on the distribution of a gall wasp species is host plant distribution. While factors like altitude (based on the vertical distance from the surface of the open seas) and regional climate are similar in some areas under comparison, the differences in the geographical distribution of oak subspecies may be attributed to the difference in the presence of the regions. This implies the important role of distribution of host plant subspecies in the determination of gall wasp distribution (Hosseinzadeh, 2012). Therefore, the diversity in the local population of oak trees at the level of species and sub species can be considered as one main factor involved in the distribution of gall wasp species besides other factors such as regional climate, annual temperature, and vegetation. Some studies indicate that the species richness of gall inducing insects increases, as air becomes hotter and drier, while other studies suggest that these factors impose no effect. The role of plant species richness in determining species richness of gall inducing insects is also controversial (Blanche, 2000). The most important point is that the role of the oak sub-species and regional climate in the distribution of oak gall wasps should not be ignored. Higher species diversity is generally supposed to display a more complex and healthier community as a greater variety of species permits more species interactions, greater system stability, and hence good environmental conditions. Oak gall wasps species richness might be expected to increase with the richness of host plant species (Starzomski et al., 2008). Besides, abiotic effects, for example, water stress, and other biotic elements such as plant age and natural enemies may likewise influence the tropical gall wasps species richness at various scales (Price, 2005; Veldtman and McGeoch, 2003). Furthermore, it has been observed that gall wasps display a high grade of host plant specificity and chemistry that might be urgent for the achievement of these insects (Cook et al., 2002; Rokas et al., 2003). Conclusions have additionally demonstrated that plant science may significantly influence the choice of plant species of gall wasps (Abrahamson et al., 2003). As an opposite pattern, with expanding the crown density, the species underneath the substantial shelter of the beech tree vanish (Brunet and Von Oheimb, 1998). Giving high measures of light and warm conditions to the woodlands floor in Querco-Carpinetum societies brought about high density and frequency of the ground layer species. According to Kwiatkowska (1994), 
Oak jungles are floristically the wealthiest woodland groups in north-west of Europe (Kwiatkowska, 1994). In the mild vegetation zone, regular and old growth woodlands still exist and can be viewed as exceptionally important living spaces as far as biodiversity. Woodlands with mild climate are greatly variable ecosystems and keep up a high diversity (Dudley, 1992). It has been proven that, the environmental is changing on the earth and also, rising of the $\mathrm{CO} 2$ production is one of the more effecting parameter on the global warming theory. These environmental changing have critical role on the biology of forest and its organisms for example; insects, plants and animals live in the forest. In addition, these changes cause altering in the nutrition, behavior and ethology of the animals (Chmura et al., 2010; Sadowski, 1996). Furthermore, the changes of climate have more significance on the class and subclass of insect pests feeding on leaves. It has been established that any changes in the environmental of the insects have significantly altered their life style and these changes are unpredictable. Generally, the change in the environmental and climatic conditions caused the growing and spread of the subclass of heat-loving insects. In addition, the environmental changing causes the disorder in the overwintering of the insects. It will increase the average of temperature as larvae, pupae and the adults showed have higher mortality further eggs have been reduced resistance. Stress and water shortages also resulted in abnormal changes in weather conditions, which causes changes in active population of insects as well as changes in type of feeding, insects have been environment (Jaworski and Hilszczański, 2013).

Table 5. Salix alba pest species richness estimated by Jackknife in 5 watersheds in West Azerbaijan Province, Iran

\begin{tabular}{|c|c|c|c|c|c|c|}
\hline \multirow{2}{*}{ Regions } & \multirow{2}{*}{ Months } & \multirow{2}{*}{$\begin{array}{l}\text { Species } \\
\text { richness }\end{array}$} & \multirow{2}{*}{ Rare species } & \multirow{2}{*}{\multicolumn{2}{|c|}{$\begin{array}{c}\text { 95\% Confidence } \\
\text { Limits } \\
\text { High Limit } \\
\text { Low Limit }\end{array}$}} & \multirow{2}{*}{$\begin{array}{l}\text { Standard } \\
\text { deviation }\end{array}$} \\
\hline & & & & & & \\
\hline \multirow{3}{*}{ Zangmar } & May & $16 / 9$ & 1 & $14 / 9$ & $18 / 9$ & $0 / 9$ \\
\hline & July & 20/9 & 1 & $18 / 9$ & $22 / 9$ & $0 / 9$ \\
\hline & October & 0 & 0 & 0 & 0 & 0 \\
\hline \multirow{3}{*}{ Mahabad } & May & $18 / 9$ & 1 & $16 / 9$ & $20 / 9$ & $0 / 9$ \\
\hline & July & $19 / 2$ & 2 & $17 / 1$ & $22 / 5$ & $1 / 2$ \\
\hline & October & $13 / 5$ & 5 & $8 / 9$ & $18 / 1$ & $2 / 01$ \\
\hline \multirow{3}{*}{ Baranduz } & May & $22 / 8$ & 2 & $20 / 1$ & $25 / 5$ & $1 / 2$ \\
\hline & July & $22 / 7$ & 3 & $19 / 6$ & $25 / 8$ & $1 / 37$ \\
\hline & October & $7 / 9$ & 1 & $5 / 9$ & 9/9 & $0 / 9$ \\
\hline \multirow{3}{*}{ Zola } & May & $18 / 9$ & 1 & $16 / 9$ & $20 / 9$ & $0 / 9$ \\
\hline & July & $23 / 6$ & 4 & $19 / 1$ & $28 / 1$ & $1 / 99$ \\
\hline & October & 0 & 0 & 0 & 0 & 0 \\
\hline \multirow{3}{*}{$\mathrm{Zab}$} & May & $17 / 9$ & 1 & $15 / 9$ & $19 / 9$ & $0 / 9$ \\
\hline & July & $16 / 9$ & 1 & $14 / 9$ & $18 / 9$ & $0 / 9$ \\
\hline & October & 0 & 0 & 0 & 0 & 0 \\
\hline
\end{tabular}


Table 6. Frequency of Salix alba pests in West Azerbaijan Province, Iran in May 2015

\begin{tabular}{ccccccc}
\hline Row & Area & Zangmar & Mahabad & Baranduz & Zola & Zab \\
& Species & & & & & \\
\hline 1 & Aphis farinosa & 45.96 & 18.38 & 10.91 & 31.08 & 26.06 \\
2 & Eriophyes tetanothrix & 19.56 & 16.32 & 4.63 & 31.71 & 3.93 \\
3 & Pontania vesicator & 0 & 8.4 & 2.88 & 3.45 & 0 \\
4 & Monosteria unicostata & 2.82 & 17.14 & 53.48 & 3.84 & 21.71 \\
5 & Chaitophorus niger & 12.97 & 12.46 & 4.03 & 5.8 & 10.5 \\
6 & Lepidosaphes malicola & 3.26 & 4.4 & 8.44 & 2.82 & 7.87 \\
7 & Tuberolachnus salignus & 3.36 & 4.95 & 2.47 & 4.39 & 4.74 \\
8 & Eulecanium coryli & 1.53 & 0.68 & 1 & 1.64 & 2.72 \\
9 & Lithocolletis salicicolla & 0 & 0.96 & 0.55 & 0.86 & 0.7 \\
10 & Rhabdophaga rosaria & 0 & 0 & 0.96 & 0.54 & 1.21 \\
11 & Cacopsylla pulchra & 1.78 & 1.92 & 0.55 & 1.49 & 1.51 \\
12 & Amorpha populi & 0 & 0.13 & 0.04 & 0 & 0 \\
13 & Eriophyes triradiatus & 0.14 & 0 & 0.55 & 1.09 & 1.51 \\
14 & Chinoaspis salicis & 1.48 & 3.99 & 1.97 & 2.74 & 5.35 \\
15 & Thrips viminalis & 1.78 & 1.92 & 2.43 & 1.88 & 2.62 \\
16 & Plagiodera versicolora & 1.48 & 0.89 & 0.41 & 0 & 0 \\
17 & Timarcha tenebricosa & 0 & 0 & 0.27 & 0 & 0 \\
18 & Chloroclysta miata & 0.34 & 1.03 & 0.36 & 0.62 & 0.9 \\
19 & Melasoma populi & 0.54 & 1.17 & 1 & 1.41 & 1.31 \\
20 & Tetranychus urtica & 2.03 & 4.2 & 2.38 & 3.45 & 6.26 \\
21 & Theria rupicapraria & 0.89 & 0.96 & 0.59 & 1.09 & 1.01 \\
\hline
\end{tabular}

Table 7. Frequency of Salix alba pests in West Azerbaijan Province, Iran in July 2015

\begin{tabular}{|c|c|c|c|c|c|c|}
\hline Row & $\begin{array}{ll}\text { Species } & \text { Area }\end{array}$ & Zangmar & Mahabad & Baranduz & Zola & Zab \\
\hline 1 & Aphis farinosa & 2.47 & 7.05 & 5.79 & 2.3 & 3.7 \\
\hline 2 & Eriophyes tetanothrix & 74.9 & 14.2 & 0 & 21.45 & 0 \\
\hline 3 & Pontania vesicator & 0.31 & 4.39 & 1.73 & 1.23 & 0 \\
\hline 4 & Monosteria unicostata & 4.75 & 17.92 & 38.25 & 22.25 & 35.33 \\
\hline 5 & Chaitophorus niger & 3.1 & 22.37 & 26.12 & 36.81 & 36.28 \\
\hline 6 & Lepidosaphes malicola & 1.13 & 1.57 & 4.14 & 4.65 & 1.68 \\
\hline 7 & Tuberolachnus salignus & 2.59 & 2.82 & 4.44 & 2.19 & 7.62 \\
\hline 8 & Eulecanium coryli & 0.54 & 0 & 1.12 & 0 & 1 \\
\hline 9 & Lithocolletis salicicolla & 2.31 & 0.82 & 0.97 & 0.53 & 0.67 \\
\hline 10 & Rhabdophaga rosaria & 0.23 & 0.49 & 2.18 & 0.42 & 0.28 \\
\hline 11 & Cacopsylla pulchra & 0.58 & 0.82 & 1.43 & 0.85 & 0.72 \\
\hline 12 & Amorpha populi & 0 & 0.08 & 0.07 & 0.05 & 0 \\
\hline 13 & Eriophyes triradiatus & 0.27 & 0.58 & 0.97 & 0.42 & 0.84 \\
\hline 14 & Chinoaspis salicis & 1.92 & 18.17 & 3.61 & 1.12 & 5.49 \\
\hline 15 & Thrips viminalis & 1.21 & 2.07 & 2.4 & 1.33 & 2.13 \\
\hline 16 & Plagiodera versicolora & 0.15 & 0 & 0.3 & 0.26 & 0 \\
\hline 17 & Timarcha tenebricosa & 0.19 & 0 & 0.15 & 0.1 & 0 \\
\hline 18 & Chloroclysta miata & 0.27 & 0.58 & 0.45 & 0.32 & 0.28 \\
\hline 19 & Melasoma populi & 0.58 & 1.9 & 1.73 & 0.9 & 1.45 \\
\hline 20 & Tetranychus urtica & 2.04 & 3.65 & 3.16 & 2.19 & 2.01 \\
\hline 21 & Theria rupicapraria & 0.35 & 0.24 & 0.9 & 0.53 & 0.44 \\
\hline
\end{tabular}




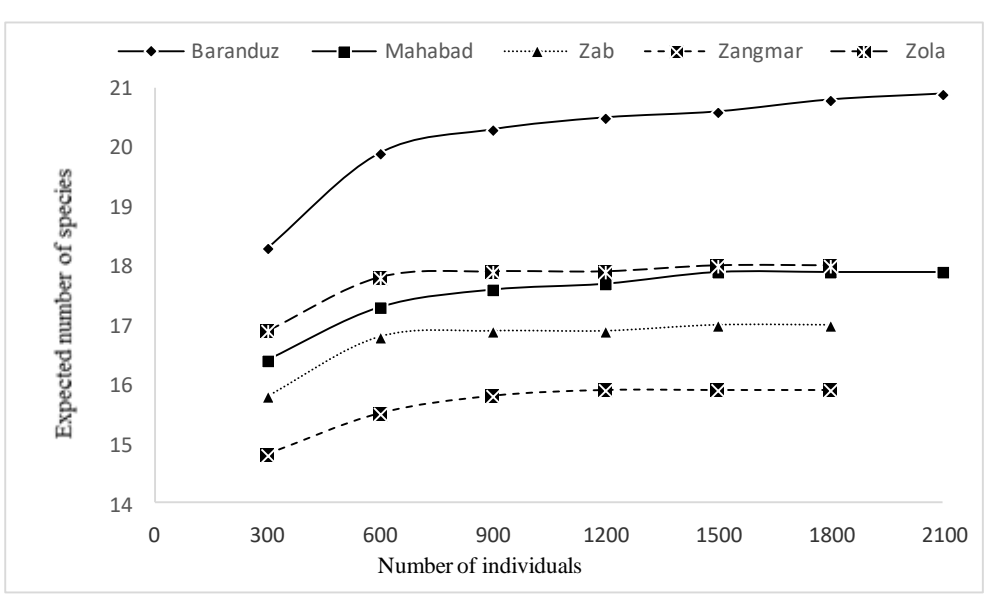

Figure 3. Salix alba pest species richness using Rarefaction method in May 2015 in West Azerbaijan Province, Iran

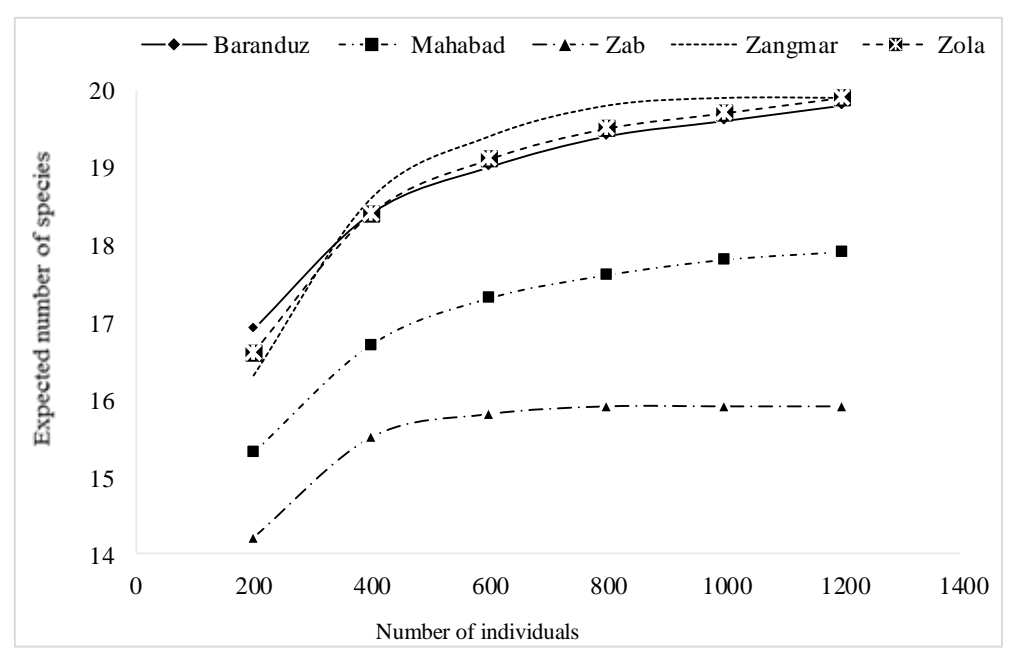

Figure 4. Salix alba pest species richness using Rarefaction method in July 2015 in West Azerbaijan Province, Iran

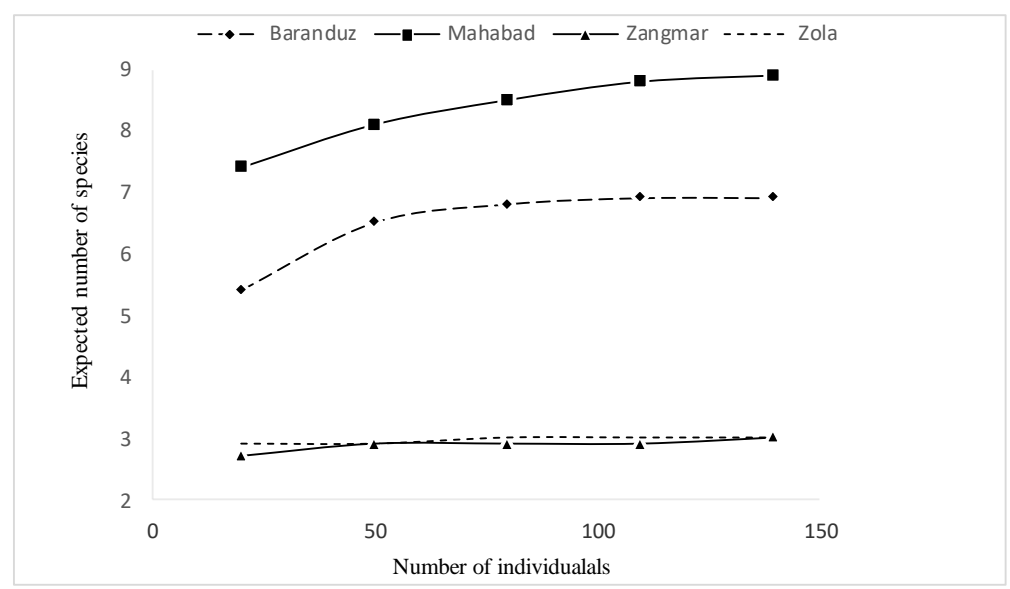

Figure 5. Salix alba pest species richness using Rarefaction method in October 2015 in West Azerbaijan Province, Iran 

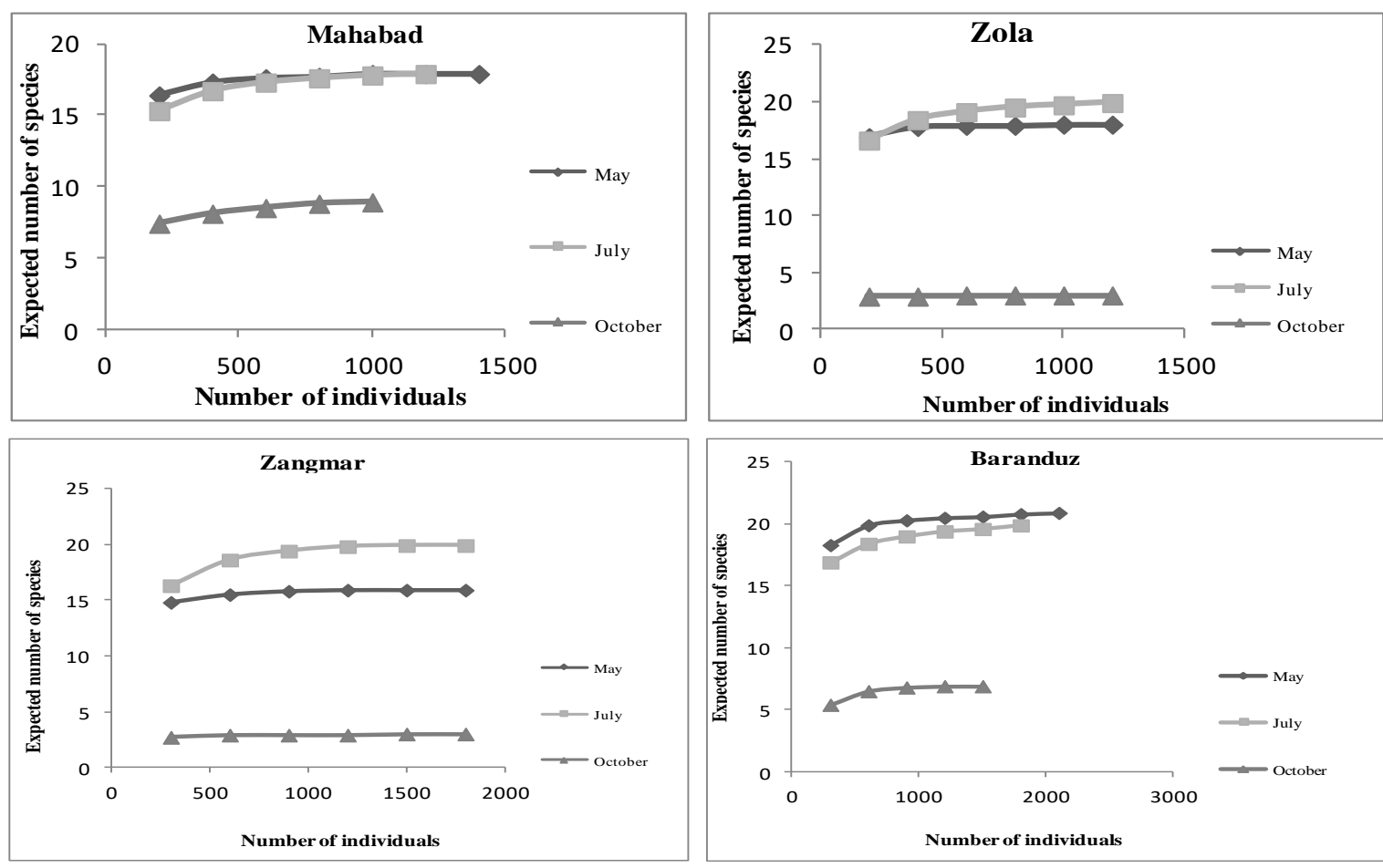

Figure 6. Salix alba pest species richness using Rarefaction method by the regions studied in different dates

Table 8. Frequency of Salix alba pests in West Azerbaijan Province, Iran in October 2015

\begin{tabular}{|c|c|c|c|c|c|c|}
\hline Row & $\begin{array}{ll}\text { Species } & \text { Area } \\
\end{array}$ & Zangmar & Mahabad & Baranduz & Zola & Zab \\
\hline 1 & Aphis farinosa & 0 & 0 & 0 & 0 & 0 \\
\hline 2 & Eriophyes tetanothrix & 48.82 & 15.73 & 8.75 & 45.24 & 0 \\
\hline 3 & Pontania vesicator & 4.68 & 15.73 & 17.5 & 7.6 & 0 \\
\hline 4 & Monosteria unicostata & 46.48 & 40.55 & 43.75 & 47.14 & 0 \\
\hline 5 & Chaitophorus niger & 0 & 9.09 & 0 & 0 & 0 \\
\hline 6 & Lepidosaphes malicola & 0 & 8.39 & 0 & 0 & 0 \\
\hline 7 & Tuberolachnus salignus & 0 & 3.14 & 0 & 0 & 0 \\
\hline 8 & Eulecanium coryli & 0 & 0.69 & 0 & 0 & 0 \\
\hline 9 & Lithocolletis salicicolla & 0 & 0 & 6.25 & 0 & 0 \\
\hline 10 & Rhabdophaga rosaria & 0 & 0 & 18.75 & 0 & 0 \\
\hline 11 & Cacopsylla pulchra & 0 & 0 & 0 & 0 & 0 \\
\hline 12 & Amorpha populi & 0 & 0.69 & 1.87 & 0 & 0 \\
\hline 13 & Eriophyes triradiatus & 0 & 0 & 3.12 & 0 & 0 \\
\hline 14 & Chinoaspis salicis & 0 & 5.94 & 0 & 0 & 0 \\
\hline 15 & Thrips viminalis & 0 & 0 & 0 & 0 & 0 \\
\hline 16 & Plagiodera versicolora & 0 & 0 & 0 & 0 & 0 \\
\hline 17 & Timarcha tenebricosa & 0 & 0 & 0 & 0 & 0 \\
\hline 18 & Chloroclysta miata & 0 & 0 & 0 & 0 & 0 \\
\hline 19 & Melasoma populi & 0 & 0 & 0 & 0 & 0 \\
\hline 20 & Tetranychus urtica & 0 & 0 & 0 & 0 & 0 \\
\hline 21 & Theria rupicapraria & 0 & 0 & 0 & 0 & 0 \\
\hline
\end{tabular}


Acknowledgement. The authors would like to thank Urmia University (Urmia, Iran) and Islamic Azad University, Arak Branch (Arak, Iran) for the administrative and technical support.

\section{REFERENCES}

[1] Abai, M. (2009): Pests of forest trees \& shrubs of Iran. - Ministry of Jiad-e Agriculture, Tehran, Iran. pp. 220.

[2] Abrahamson, W. G., Hunter, M. D., Melika, G., Price, P. W. (2003): Cynipid gall-wasp communities correlate with oak chemistry. - Journal of Chemical Ecology 29(1): 209223.

[3] Alatalo, R. V. (1981): Problems in the measurement of evenness in ecology. - Oikos 37(2): 199-204.

[4] Ashori, A., Kheradpir, N. (2009): Inset Ecology. - Tehran University, Tehran, Iran. pp.579.

[5] Belyaeva, I. (2009): Nomenclature of Salix fragilis L. and a new species, S. euxina (Salicaceae). - Taxon 58(4): 1344-1348.

[6] Blanche, K. (2000): Diversity of insect-induced galls along a temperature-rainfall gradient in the tropical savannah region of the Northern Territory, Australia. - Austral Ecology 25(4): 311-318.

[7] Brunet, J., Von Oheimb, G. (1998): Migration of vascular plants to secondary woodlands in southern Sweden. - Journal of Ecology 86(3): 429-438.

[8] Chmura, D. J., Howe, G. T., Anderson, P., St Clair, J. B. (2010): Adaptation of trees, forests and forestry to climate change. - Sylwan 154(9): 587-602.

[9] Cook, J. M., Rokas, A., Pagel, M. Stone, G. N. (2002): Evolutionary shifts between host oak sections and host-plant organs in Andricus gallwasps. - Evolution 56(9): 1821-1830.

[10] Dudley, N. (1992): Forests in trouble: a review of the status of temperate forests worldwide. WWF, University of Michigan.

[11] Ejtehadi, H., Sepehry, A., Akkafi, H. (2009): Methods of measuring biodiversity. Ferdowsi University of Mashhad, Iran.

[12] Hageneder, F. (2005): The Meaning of Trees: Botany-History-Healing-Lore. - Chronicle Books, San Fransisco.

[13] Hawksworth, D., Kalin-Arroyo, M. (1995): Magnitude and distribution of biodiversity. In: Heywood, H. V. (ed.) Global Biodiversity Assessment. Cambridge University Press, Cambridge.

[14] Hosseinzadeh, A. (2012): Species richness and true diversity of cynipid galling-wasps community in oak forests of West-Azerbaijan Province (Iran). - African Journal of Biotechnology 11(36): 8912-8919.

[15] Jaworski, T., Hilszczański, J. (2013): The effect of temperature and humidity changes on insects development their impact on forest ecosystems in the expected climate change. Forest Research Papers 74(4): 345-355.

[16] Krebs, C. J. (1989): Ecological methodology. - Harper \& Row, New York.

[17] Kwiatkowska, A. J. (1994): Changes in the species richness, spatial pattern and species frequency associated with the decline of oak forest. - Vegetatio 112(2): 171-180.

[18] Magurran, A. E. (2013): Measuring biological diversity. - John Wiley \& Sons, USA.

[19] Price, P. W. (2005): Adaptive radiation of gall-inducing insects. - Basic and Applied Ecology 6(5): 413-421.

[20] Rokas, A., Atkinson, R. J., Webster, L., Csóka, G., Stone, G. N. (2003): Out of Anatolia: longitudinal gradients in genetic diversity support an eastern origin for a circum-Mediterranean oak gallwasp Andricus quercustozae. - Molecular Ecology 12(8): 2153-2174.

[21] Sadeghi, S. E., Yarmand, H., Zamani, M. S., Ali, B., Zeinaly, S., Mehrabi, A., Talebi, A. A., Azizkhani, E. (2009): Insects associated with forest communities and poplar 
plantations in Iran. - In: Kharazipour, R. A., Schöpper, C., Müller, C., Euring, M. Review of Forest, Wood Products and Wood Biotechnology of Iran and Germany. Universitätverlag Göttingen, Germany.

[22] Sadowski, M. (1996): Przewidywane zmiany klimatu i ich przyrodnicze, spoleczne i polityczne konsekwencje. - Sylwan 5(140): 83-103.

[23] Sandlund, O., Hindar, K. Brown, A. (1992): Conservation of biodiversity for sustainable development. - Oxford University Press, Oxford.

[24] Schowalter, T. D. (2006): Insect ecology: an ecosystem approach. - Academic Press, USA.

[25] Southwood, T. R. E., Henderson, P. A. (2009): Ecological methods. - Wiley-Blackwell, USA.

[26] Speight, M. R., Hunter, M. D., Watt, A. D. (1999): Ecology of insects: concepts and applications. - Blackwell Science Ltd., USA

[27] Starzomski, B. M., Parker, R. L., Srivastava, D. S. (2008): On the relationship between regional and local species richness: a test of saturation theory. - Ecology 89(7): 19211930.

[28] Stettler, R. F. (2011): Cottonwood and the river of time: on trees, evolution, and society.University of Washington Press, Washington.

[29] Stirling, G., Wilsey, B. (2001): Empirical relationships between species richness, evenness, and proportional diversity. - The American Naturalist 158(3): 286-299.

[30] Veldtman, R., McGeoch, M. (2003): Gall-forming insect species richness along a non-scleromorphic vegetation rainfall gradient in South Africa: The importance of plant community composition. - Austral Ecology 28(1): 1-13. 